\title{
Active Chloride Secretion in the Normal Human Jejunum
}

\author{
Glenn R. Davis, Carol A. Santa Ana, Stephen Morawski, and \\ John S. FordTRAN, Department of Medicine, Baylor University Medical Center, \\ Dallas, Texas 75246
}

\begin{abstract}
A в S T R A C T To determine whether the small intestine normally secretes fluid, it would be necessary to reduce or inhibit the greater absorptive processes that would otherwise mask such secretion if present. To do this, we perfused bicarbonate-free solutions in the jejunum of normal subjects, because it has been shown that active absorption from this part of the human small intestine is dependent on luminal bicarbonate. We found that the jejunum did secrete sodium chloride and water when isotonic bicarbonate-free solutions were perfused. Further studies revealed that the sodium secretion was passive, but that chloride was secreted against an electrochemical gradient and that observed chloride flux ratios did not agree with the flux ratios calculated for passive chloride movement. We conclude, therefore, that the normal jejunum actively secretes chloride, but that this is masked by greater absorptive processes when balanced electrolyte solutions are perfused. The rate of this active chloride secretion may be one of the factors that regulate the rate of fluid absorption in the normal human intestine.
\end{abstract}

\section{INTRODUCTION}

When the normal human small intestine is perfused with balanced electrolyte solutions, the overall effect of its transport processes is absorption of the luminal fluid. However, it has been suggested that the small bowel also secretes fluid normally, but that this is masked by higher rates of intestinal absorption (1).

Further information about this hypothesis might be obtained if it were possible to inhibit the normal absorptive mechanisms by some nonpathologic means that would not stimulate secretion. It seemed that we could do this in the normal human jejunum by simply

This study was presented in part at the American Gastroenterological Association Meeting in May 1980, at Salt Lake City, Utah. It appeared in abstract form in 1980. Gastroenterology. 78: 1153.

Received for publication 24 April 1980 and in revised form 1 August 1980. eliminating bicarbonate from the perfused test solution. This is because active absorption of electrolytes from the human jejunum in vivo is dependent on luminal bicarbonate (2). If bicarbonate-free solutions are perfused, intestinal secretion should result if the normal human jejunum is a secretory as well as an absorptive organ.

\section{METHODS}

\section{Measurement of absorption-secretion}

Perfusion studies were carried out in the standard fashion using the triple-lumen method (3). The mixing segment was 10 $\mathrm{cm}$, and the test segment was $30 \mathrm{~cm}$. The studies were started when the infusion site was located at the ligament of Treitz as determined by fluoroscopy. The test solutions were infused at $10 \mathrm{ml} / \mathrm{min}$. Equilibration periods were $50 \mathrm{~min}$, and the collection periods were $60 \mathrm{~min}$. The collections from the proximal and distal collecting sites were staggered by $10 \mathrm{~min}$, and samples were aspirated from these sites at $1.5 \mathrm{ml} / \mathrm{min}$.

The test solutions were isotonic and contained varying concentrations of $\mathrm{Na}, \mathrm{K}, \mathrm{Cl}, \mathrm{HCO}_{3}, \mathrm{SO}_{4}$, and mannitol. To some test solutions ${ }^{36} \mathrm{Cl}$ and ${ }^{24} \mathrm{Na}(0.5 \mu \mathrm{Ci}$ /liter $)$ were added. Each test solution contained polyethylene glycol, 2 g/liter, as a nonabsorbable marker. The exact makeup of each test solution is given in the Results section.

\section{Potential difference}

Potential difference (PD) ${ }^{1}$ was measured $(a)$ directly via a flowing saline electrode, and $(b)$ in some experiments indirectly via the equilibration concentration of an ion $\left(\mathrm{K}^{+}\right)$ that is distributed across the intestinal mucosa according to electrochemical gradients.

Direct measurement. PD was measured continuously between a flowing intraluminal electrode and a subcutaneous reference electrode, as recently described in detail (4). Briefly, the reference electrode consisted of saline in a Medicut catheter (Sherwood Medical Industries, St. Louis, Mo.) inserted into the subcutaneous tissue of the dorsal aspect of the forearm. (In dogs, a subcutaneous reference site has been shown to give results similar to a reference electrode placed on serosa of intestine [5].) This subcutaneous reference and the flowing intraluminal catheter were connected via 3-M

${ }^{1}$ Abbreviation used in this paper: $\mathrm{PD}$, potential difference. 
$\mathrm{KCl}$ agar bridges and calomel half-cells to the input terminals of a battery-powered electrometer (model 602, Keithley Instruments, Inc., Cleveland, Ohio), and the output was displayed on a chart recorder (model 281, Rikadenki, Tokyo, Japan).

Preliminary studies revealed that when the infused test solution was used as the flowing electrode, results were similar to when a flowing electrode (consisting of normal saline infused at a rate of $0.15 \mathrm{ml} / \mathrm{min}$ ) was situated at the midpoint of the test segment $(25 \mathrm{~cm}$ from the infusion site via a fourth tube attached to the standard triple-lumen perfusion tube). For example, during perfusion of a bicarbonate-free solution, the PD was $-3.7 \pm 0.7 \mathrm{mV}$ at the infusion site and $-3.9 \pm 0.7 \mathrm{mV}$ at the midpoint of the test segment in five normal subjects. Therefore, in further studies we used the infused test solution as the flowing electrode because it reduced the number of necessary tubes, and therefore the size of the perfusion assembly. It also avoided the addition of extra solution in the middle of the test segment which, though small in volume, would have interfered with accurate measurement of transport rates.

As shown in Table I, PD by this method changed as expected in response to varying the luminal concentration of glucose (sodium transport potential) and sodium (sodium diffusion potential).

Indirect measurement. Previous studies have shown that potassium movement across small bowel mucosa is passive in accord with electrochemical gradients (6), and is equilibrated by the time fluid reaches the distal collecting site during intestinal perfusion (7). Therefore, PD across the mucosa was estimated from a comparison of luminal potassium concentration at the distal collecting site and serum potassium concentration by means of the Nernst equation $(8,9)$.

\section{Analysis of samples}

Infused test solutions and aspirated samples obtained from the proximal and distal ends of the test segment were analyzed for polyethylene glycol by the Hyden method (10) and for sodium and potassium concentrations by flame photometer (model 343, Instrumentation Laboratory, Inc., Lexington, Mass.). Chloride and bicarbonate were determined with a Beckman chloride/carbon dioxide analyzer (Beckman Instruments, Fullerton, Calif.). Osmolality was determined with an Advanced Instruments osmometer (model 3D11, Advanced

TABLE I

Measured $P D^{*}$ during Jejunal Perfusion of Four Test Solutions

\begin{tabular}{ccccc}
\hline Subject & $\begin{array}{c}50 \mathrm{mM} \\
\mathrm{NaCl}+170 \\
\mathrm{mM} \text { man- } \\
\text { nitol }\end{array}$ & $\begin{array}{c}100 \mathrm{mM} \\
\mathrm{NaCl}+80 \\
\mathrm{mM} \text { man- } \\
\text { nitol }\end{array}$ & $\begin{array}{c}150 \mathrm{mM} \\
\mathrm{NaCl}\end{array}$ & $\begin{array}{c}100 \mathrm{mM} \\
\mathrm{NaCl}+80 \\
\mathrm{mM} \text { glucose }\end{array}$ \\
\hline 1 & +4.5 & -5.0 & -5.0 & -11.5 \\
2 & +6.0 & 0 & -6.0 & -9.0 \\
3 & +4.0 & 0 & -4.0 & -10.0 \\
4 & +4.5 & +0.5 & -3.5 & -12.0 \\
5 & +7.5 & +5.0 & -3.0 & -6.0 \\
Mean $\pm \mathrm{SE}$ & $+5.3 \pm 0.6$ & $+0.1 \pm 1.6$ & $-4.3 \pm 0.5$ & $-9.7 \pm 1.1$
\end{tabular}

All differences in PD are statistically significant, at least $P<0.025$, by Student's paired $t$ test.

${ }^{*}(+)$ indicates lumen-positive PD; (-) indicates lumennegative $\mathrm{PD}$.
Instruments, Inc., Needham Heights, Mass.). The $\mathrm{pH}$ and $\mathrm{PCO}_{2}$ were determined with a blood gas analyzer (Instrumentation Laboratory). ${ }^{36} \mathrm{Cl}$ and ${ }^{24} \mathrm{Na}$ were assayed in a Packard 2425 liquid scintillation spectrometer (Packard Instrument Co., Inc., Downers Grove, Ill.).

\section{Calculations}

Net water and electrolyte movements were calculated by standard nonabsorbable marker equations (11). Unidirectional fluxes were calculated by the equation of Berger and Steele (12), and calculated flux ratios for passive ion movement were measured by the Ussing equation (13).

\section{Ethical consideration}

This research was approved by a human research review committee on June 1, 1979, and informed written consent was obtained from each participant.

\section{RESULTS}

Effect of varying luminal bicarbonate concentration on water and electrolyte movement. In five normal subjects, three test solutions were perfused in a random order. The composition of these test solutions is given in the footnote to Table II. Solution A was a bicarbonatefree solution. Solution B contained $30 \mathrm{mM}$ bicarbonate, a concentration similar to plasma, while solution C contained a high bicarbonate concentration $(55 \mathrm{mM})$ so that the mean concentration of bicarbonate in the test segment was approximately the same as plasma.

The results are shown in Table II. Absorption of water and electrolytes occurred during perfusion of both bicarbonate-containing solutions $\mathrm{B}$ and $\mathrm{C}$. When bicarbonate was omitted from test solution A, not only was absorption not observed, but the jejunum secreted water, sodium, and chloride. This could not be attributed to concentration gradients of sodium and chloride or to hyperosmolality of luminal fluid. ${ }^{2}$ Therefore, these results suggest active electrolyte secretion of some type by the normal jejunal mucosa, presumably either active sodium or chloride secretion. The PD was similar in all studies, with the lumen being negative by both direct and indirect measurements.

Further studies with the bicarbonate-free solution. 12 additional subjects were perfused with the bicarbonate-free solution (A), as in the preliminary studies above. In addition, ${ }^{36} \mathrm{Cl}$ was added to every solution, and ${ }^{24} \mathrm{Na}$ was added to the test solution when the isotope was available, so that unidirectional fluxes and observed flux ratio could be determined. Potential difference and the plasma concentration of sodium and chloride were measured, and the calculated flux ratio

2 The effective osmotic pressure of luminal fluid should not be higher than that of plasma since nonpermeable sulfate and mannitol in the lumen are balanced by nonpermeable solutes in plasma, such as bicarbonate. 
TABLE II

Effect of Varying the Infused Bicarbonate Concentration on Net Water and Electrolyte Movement in Five Normal Subjects

\begin{tabular}{|c|c|c|c|c|c|c|c|c|c|c|}
\hline \multirow[b]{2}{*}{ Solution 1} & \multicolumn{4}{|c|}{$\begin{array}{l}\text { Mean electrolyte concentration and } \\
\text { osmolality in test segment }\end{array}$} & \multicolumn{4}{|c|}{ Net movement* } & \multicolumn{2}{|c|}{ PD } \\
\hline & Sodium & Bicarbonate & Chloride & Osmolality & $\mathrm{H}_{2} \mathrm{O}$ & $\mathrm{Na}$ & $\mathrm{HCO}_{3}$ & $\mathrm{Cl}$ & Direct & Indirect \\
\hline & & mequliter & & mosmol/kg & $\mathrm{ml} / \mathrm{h} / 30 \mathrm{~cm}$ & & $e q / h / 30 \mathrm{~cm}$ & & & \\
\hline A & $\begin{array}{r}146.2 \\
\pm 0.9\end{array}$ & $\begin{array}{r}0.5 \\
\pm 0.1\end{array}$ & $\begin{array}{r}100.6 \\
\pm 0.6\end{array}$ & $\begin{array}{r}284 \\
\pm 1\end{array}$ & $\begin{array}{l}+14 \\
\pm 12\end{array}$ & $\begin{array}{l}+3.1 \\
\pm 1.6\end{array}$ & $\begin{array}{l}+0.1 \\
\pm 0.1\end{array}$ & $\begin{array}{l}+4.2 \\
\pm 1.5\end{array}$ & $\begin{array}{l}-3.8 \\
\pm 0.9\end{array}$ & $\begin{array}{l}-4.9 \\
\pm 1.8\end{array}$ \\
\hline B & $\begin{array}{r}144.6 \\
\pm 1.0\end{array}$ & $\begin{array}{r}9.4 \\
\pm 1.0\end{array}$ & $\begin{array}{r}111.2 \\
\pm 1.0\end{array}$ & $\begin{array}{r}282 \\
\pm 1\end{array}$ & $\begin{array}{c}-96 \S \\
\pm 3\end{array}$ & $\begin{array}{c}-12.3 \S \\
\pm 0.1\end{array}$ & $\begin{array}{l}-7.8 \S \\
\pm 0.8\end{array}$ & $\begin{array}{l}-3.0^{\|} \\
\pm 0.7\end{array}$ & $\begin{array}{l}-3.9 \\
\pm 0.9\end{array}$ & $\begin{array}{l}-5.5 \\
\pm 1.5\end{array}$ \\
\hline $\mathrm{C}$ & $\begin{array}{r}143.2 \\
\pm 1.4\end{array}$ & $\begin{array}{r}29.7 \\
\pm 4.4\end{array}$ & $\begin{array}{r}116.3 \\
\pm 3.2\end{array}$ & $\begin{array}{r}283 \\
\pm 1\end{array}$ & $\begin{array}{c}-172 \S \\
\pm 26\end{array}$ & $\begin{array}{c}-24.1 \S \\
\pm 4.1\end{array}$ & $\begin{array}{c}-16.3 \S \\
\pm 2.3\end{array}$ & $\begin{array}{l}-8.9 \text { I } \\
\pm 2.1\end{array}$ & $\begin{array}{l}-4.0 \\
\pm 0.9\end{array}$ & $\begin{array}{l}-5.2 \\
\pm 2.0\end{array}$ \\
\hline
\end{tabular}

$*(-)=$ net absorption; $(+)=$ net secretion.

$\$$ All test solutions (A, B, C) contained (mmol/liter) Na 145, K 5, Cl 95. Solution A was bicarbonate free and contained $27.5 \mathrm{mM}$ sulfate and $30 \mathrm{mM}$ mannitol. Solution B contained $30 \mathrm{mM}$ bicarbonate, $12.5 \mathrm{mM}$ sulfate, and $10 \mathrm{mM}$ mannitol. Solution C contained $55 \mathrm{mM}$ bicarbonate.

$\S P<0.001$ when compared with solution A by Student's paired $t$ test.

" $P<0.02$ when compared with solution A by Student's paired $t$ test.

I $P<0.01$ when compared with solution A by Student's paired $t$ test.

for sodium and chloride were determined by the secretion of chloride in 11 of the 12 subjects. In these Ussing equation.

subjects the secretion of chloride occurred in spite of a

The results are shown in Table III. There was net lumen-negative PD (mean $-3.8 \mathrm{mV}$ direct, $-5.4 \mathrm{mV}$

TABLE III

Jejunal Perfusion with a Bicarbonate-free Solution in 12 Normal Subjects

\begin{tabular}{|c|c|c|c|c|c|c|c|c|c|c|c|c|c|c|c|c|}
\hline \multirow[b]{4}{*}{ Subject } & \multirow{2}{*}{\multicolumn{2}{|c|}{$\begin{array}{l}\text { Mean concen- } \\
\text { tration in test } \\
\text { segment }^{*}\end{array}$}} & \multirow{2}{*}{\multicolumn{2}{|c|}{ PD 1}} & \multirow{3}{*}{\multicolumn{4}{|c|}{ Net movement $\S$}} & & \multirow{2}{*}{\multicolumn{2}{|c|}{ Sodium flux ratio }} & \multirow{2}{*}{\multicolumn{2}{|c|}{ Chloride flux ratio }} \\
\hline & & & & & & & & & \multicolumn{4}{|c|}{ Unidirectional fluxes } & & & & \\
\hline & \multirow{2}{*}{$\begin{array}{c}\text { So- } \\
\text { dium }\end{array}$} & \multirow{2}{*}{$\begin{array}{l}\text { Chlo- } \\
\text { ride }\end{array}$} & \multirow[b]{2}{*}{ Direct } & \multirow{2}{*}{$\begin{array}{c}\text { In- } \\
\text { direct }\end{array}$} & & & & & \multicolumn{2}{|c|}{ Sodium } & \multicolumn{2}{|c|}{ Chloride } & \multirow{2}{*}{$\begin{array}{c}\text { Ob- } \\
\text { served }\end{array}$} & \multirow{2}{*}{$\begin{array}{l}\text { Calcu- } \\
\text { lated" }\end{array}$} & \multirow{2}{*}{$\begin{array}{c}\text { Ob- } \\
\text { served }\end{array}$} & \multirow{2}{*}{$\begin{array}{l}\text { Calcu- } \\
\text { lated" }\end{array}$} \\
\hline & & & & & $\mathrm{H}_{2} \mathrm{O}$ & $\mathrm{Na}$ & $\mathrm{HCO}_{3}$ & $\mathrm{Cl}$ & $\mathrm{L}>\mathrm{P}$ & $\mathrm{P}>\mathrm{L}$ & $\mathrm{L}>\mathrm{P}$ & $P>L$ & & & & \\
\hline & \multicolumn{2}{|c|}{ meq/liter } & \multicolumn{2}{|c|}{$m V$} & \multicolumn{4}{|c|}{$m l$ or meq $/ \mathrm{h} / 30 \mathrm{~cm}$} & \multicolumn{4}{|c|}{$m e q / h / 30 \mathrm{~cm}$} & & & & \\
\hline 1 & 143.3 & 98.8 & -5.5 & NA & +42 & +6.6 & +0.1 & +8.2 & - & - & 25.4 & 33.6 & - & - & 0.76 & 1.23 \\
\hline 2 & 147.0 & 100.8 & -4.5 & -4.4 & +15 & +2.8 & +0.2 & +2.8 & - & - & 15.2 & 18.0 & - & - & 0.84 & 1.17 \\
\hline 3 & 145.2 & 100.2 & -4.5 & -8.2 & -26 & -2.1 & +0.1 & -0.4 & - & - & 15.9 & 15.5 & - & - & 1.02 & 1.14 \\
\hline 4 & 148.6 & 100.5 & -4.0 & -7.1 & 0 & +2.0 & +0.2 & +3.8 & - & - & 27.8 & 31.6 & - & - & 0.88 & 1.11 \\
\hline 5 & 146.9 & 102.5 & -0.5 & 0.0 & +37 & +6.3 & +0.1 & +6.4 & - & - & 24.8 & 31.2 & - & - & 0.79 & 0.98 \\
\hline 6 & 135.8 & 113.8 & -6.0 & NA & +23 & +5.1 & +0.9 & +8.0 & - & - & 17.7 & 25.7 & - & - & 0.69 & 1.29 \\
\hline 7 & 138.8 & 111.0 & -2.5 & -5.1 & -3 & +1.6 & +0.1 & +0.9 & 65.6 & 67.2 & 34.6 & 35.5 & 0.98 & 0.90 & 0.97 & 1.16 \\
\hline 8 & 137.9 & 109.0 & -1.5 & -5.6 & +29 & $\begin{array}{r}+4.3 \\
\end{array}$ & +0.6 & $\begin{array}{r}+5.2 \\
\end{array}$ & 42.4 & & 26.4 & 31.6 & 0.91 & 0.93 & 0.84 & 1.10 \\
\hline 9 & 136.0 & 108.0 & -2.0 & -6.2 & +4 & +1.4 & 0.0 & +1.1 & 31.9 & 33.0 & 21.6 & 22.7 & 0.97 & 0.91 & 0.97 & 1.08 \\
\hline 10 & 134.8 & 109.2 & -4.5 & -10.4 & +6 & +4.4 & 0.0 & +2.9 & 46.6 & 51.0 & 21.4 & 24.8 & 0.91 & 0.81 & 0.88 & 1.17 \\
\hline 11 & 141.4 & 113.5 & -4.3 & -1.7 & +31 & +5.4 & +1.1 & +4.2 & 43.4 & 48.8 & 18.3 & 22.5 & 0.89 & 0.86 & 0.81 & 1.20 \\
\hline 12 & 140.4 & 112.8 & -6.0 & -5.4 & -17 & +0.1 & -1.3 & +1.8 & - & - & 32.7 & 34.5 & - & - & 0.94 & 1.33 \\
\hline \multirow{2}{*}{$\begin{array}{l}\text { Mean } \\
\pm \text { SEM }\end{array}$} & 141.3 & 106.7 & -3.8 & -5.4 & +12 & +3.2 & +0.2 & +3.7 & 46.0 & 49.3 & 23.5 & 27.3 & 0.93 & 0.88 & 0.86 & $1.16 \pi$ \\
\hline & \pm 1.4 & \pm 1.6 & \pm 0.5 & \pm 0.9 & \pm 6 & \pm 0.8 & \pm 0.2 & \pm 0.8 & \pm 5.5 & \pm 5.4 & \pm 1.8 & \pm 1.9 & \pm 0.02 & \pm 0.02 & \pm 0.03 & \pm 0.03 \\
\hline
\end{tabular}

Mean serum sodium in the 12 subjects was $140.8 \pm 0.5$ meq/liter; mean serum chloride was $106.2 \pm 0.9$ meq/liter; mean serum osmolality was $285 \pm 1$.

* Mean concentration is the arithmetic mean of the concentration at the proximal and distal sites.

$\ddagger N A$ indicates serum potassium not available because specimen was hemolyzed.

$\S(-)=$ net absorption; $(+)=$ net secretion. The mean net potassium movement was $0.0 \pm 0.1$. The difference in the net cation and net anion movement is $0.4 \mathrm{meq} / \mathrm{h} / 30 \mathrm{~cm}$, which may represent sulfate absorption.

"Calculated flux ratio was determined using directly measured PD.

I $P<0.001$ when compared with observed chloride flux ratio (Student's paired $t$ test). 
indirect) and in the absence of any concentration gradient between plasma and lumen. These observations indicate that chloride was secreted against an electrochemical gradient. Moreover, the observed chloride flux ratio was significantly less $(P<0.001)$ than the calculated flux ratio for passive movement in all 12 subjects.

In contrast, sodium moved (was secreted) in the direction favored by the lumen-negative $\mathrm{PD}$, while the lumen and plasma concentrations of sodium were similar. In addition, the observed sodium flux ratio was not significantly different from the calculated flux ratio for passive movement. This suggested that sodium secretion was passive.

Perfusion with bicarbonate-free and sulfate-free solution. The bicarbonate-free solution used in the previous studies contained sulfate. To be certain that the sulfate was not in some way responsible for the observed chloride secretion, we perfused the jejunum of normal subjects with a bicarbonate-free and sulfatefree solution containing 120 or $100 \mathrm{mM} \mathrm{NaCl}$. These solutions were made isosmotic by the addition of mannitol. The results are shown in Table IV. With the $120 \mathrm{mM}$ solution, chloride was secreted at a rate of 3.7 $\mathrm{meq} / \mathrm{h}$ per $30 \mathrm{~cm}$, while the $P D$ was -1.5 (lumen negative), and the mean luminal chloride concentration was $119 \mathrm{meq} / \mathrm{liter}$. The observed chloride flux ratio was less than the calculated flux ratio. A similar difference in observed and calculated chloride flux ratios was seen with the $100 \mathrm{mM} \mathrm{NaCl}$ solution, where the mean luminal chloride concentration was $111 \mathrm{meq} / \mathrm{liter}$ and the PD was +0.5 (lumen positive). Therefore, the active chloride secretion observed in studies described in the previous section cannot be ascribed to sulfate in the luminal fluid.

Effect of cimetidine. Since cimetidine is known to inhibit $\mathrm{HCl}$ secretion by the stomach, we investigated the effect of this drug on chloride secretion in the jejunum. Six additional normal subjects were perfused with a bicarbonate-free solution as above. Mean net sodium and chloride secretion were again observed at rates of 3.9 and $5.1 \mathrm{meq} / \mathrm{h}$ per $30 \mathrm{~cm}$, respectively. An intravenous bolus injection of $300 \mathrm{mg}$ cimetidine was given, and was followed by a continuous infusion of cimetidine at a rate of $75 \mathrm{mg} / \mathrm{h}$. As shown in Table V, cimetidine had no significant effect on net secretion rate of water and electrolytes or on PD.

pH and $\mathrm{PCO}_{2}$. To determine whether the active chloride secretion was associated with hydrogen secretion, five additional normal subjects were perfused with a bicarbonate-free and a bicarbonate-containing balanced electrolyte solution that were continuously bubbled with $5 \% \mathrm{CO}_{2}-95 \% \mathrm{O}_{2}$. Aspirated fluid from the proximal and distal collecting sites was collected anaerobically in well-fitting syringes and sealed at termination of the collection. $\mathrm{PCO}_{2}$ and $\mathrm{pH}$ were then measured immediately. Cimetidine was administered intravenously during both of these studies to reduce gastric acid secretion. (If gastric acid were emptied into the small intestine, it would lower the luminal $\mathrm{pH}$, react with luminal bicarbonate, and raise the $\mathrm{PCO}_{2}$. It was therefore necessary to inhibit gastric acid secretion in order to determine whether the chloride secretion by the jejunal mucosa is associated with hydrogen ion secretion.)

The results are shown in Table VI. With the bicar-

TABLE IV

Effect of Bicarbonate-free and Sulfate-free Solutions on Chloride Transport

\begin{tabular}{|c|c|c|c|c|c|c|c|c|c|c|c|c|}
\hline \multirow[b]{3}{*}{ Solution } & \multirow[b]{3}{*}{ Subject } & \multirow{2}{*}{\multicolumn{2}{|c|}{$\begin{array}{l}\text { Mean concentration } \\
\text { intestinal segment }\end{array}$}} & \multirow{3}{*}{$\frac{\mathrm{PD}^{*}}{\text { Direct }}$} & \multirow{2}{*}{\multicolumn{4}{|c|}{ Net movementt }} & \multirow{2}{*}{\multicolumn{2}{|c|}{$\begin{array}{l}\text { Unidirectional } \\
\text { chloride flux }\end{array}$}} & \multicolumn{2}{|c|}{ Chloride flux ratio } \\
\hline & & & & & & & & & & & \multirow{2}{*}{$\begin{array}{l}\text { Ob- } \\
\text { served }\end{array}$} & \multirow{2}{*}{$\begin{array}{l}\text { Calcu- } \\
\text { lated }\end{array}$} \\
\hline & & Sodium & Chloride & & $\mathrm{H}_{2} \mathrm{O}$ & $\mathrm{Na}$ & $\mathrm{HCO}_{3}$ & $\mathrm{Cl}$ & $\mathrm{L}>\mathrm{P}$ & $\mathrm{P}>\mathrm{L}$ & & \\
\hline & & \multicolumn{2}{|c|}{ mequlliter } & $m V$ & & \multicolumn{3}{|c|}{$\mathrm{ml}$ or meq/h/30 cm } & \multicolumn{2}{|c|}{$m e q / h / 30 \mathrm{~cm}$} & & \\
\hline \multirow[t]{3}{*}{$120 \mathrm{mM} \mathrm{NaCl}$} & 1 & 120.6 & 117.8 & 0 & +33 & +4.7 & +0.1 & +4.9 & 43.0 & 47.9 & 0.90 & 1.12 \\
\hline & 2 & 119.4 & 121.2 & -2.5 & +40 & +4.2 & +0.1 & +5.1 & 39.8 & 44.9 & 0.89 & 1.27 \\
\hline & 3 & 117.4 & 119.0 & -2.0 & +21 & +1.2 & -0.1 & +1.2 & 26.9 & 28.1 & 0.96 & 1.21 \\
\hline \multirow[t]{2}{*}{ Mean \pm SEM } & & 119.1 & 119.3 & -1.5 & +31 & +3.4 & +0.03 & +3.7 & 36.6 & 40.3 & 0.92 & 1.20 \\
\hline & & \pm 0.9 & \pm 1.0 & \pm 0.8 & \pm 6 & \pm 1.1 & \pm 0.07 & \pm 1.3 & \pm 4.9 & \pm 6.2 & \pm 0.07 & \pm 0.04 \\
\hline \multirow[t]{3}{*}{$100 \mathrm{mM} \mathrm{NaCl}$} & 1 & 109.6 & 110.2 & -0.5 & +49 & +7.8 & -0.3 & +7.7 & 21.8 & 29.5 & 0.74 & 1.07 \\
\hline & 2 & 109.8 & 113.2 & +1.5 & +52 & +9.6 & +0.2 & +9.8 & 31.1 & 40.9 & 0.76 & 1.02 \\
\hline & 3 & 110.6 & 109.3 & +0.5 & +61 & +9.0 & +1.3 & +9.2 & 18.1 & 27.3 & 0.66 & 1.01 \\
\hline \multirow[t]{2}{*}{ Mean \pm SEM } & & 110.0 & 111.1 & +0.5 & +54 & +8.8 & +0.4 & +8.9 & 23.7 & 32.6 & 0.72 & 1.03 \\
\hline & & \pm 0.3 & \pm 1.1 & \pm 0.6 & \pm 4 & \pm 0.5 & \pm 0.5 & \pm 0.6 & \pm 3.8 & \pm 4.2 & \pm 0.03 & \pm 0.02 \\
\hline
\end{tabular}

* Only direct measurement for PD available since test solution did not contain potassium.

$\ddagger(-)=$ net absorption; $(+)=$ net secretion. 
TABLE V

Effect of Cimetidine on Active Chloride Secretion during Perfusion of a Bicarbonate-free Solution in Six Normal Subjects

\begin{tabular}{|c|c|c|c|c|c|c|}
\hline & \multicolumn{5}{|c|}{ Net movement* } & \multirow[b]{2}{*}{ Direct PD } \\
\hline & Water & $\mathrm{Na}$ & $\mathbf{K}$ & $\mathrm{Cl}$ & $\mathrm{HCO}_{3}$ & \\
\hline & \multicolumn{5}{|c|}{$\mathrm{ml}$ or $\mathrm{meq} / \mathrm{h} / 30 \mathrm{~cm}$} & $m V$ \\
\hline Without cimetidine & $+22 \pm 16$ & $+3.9 \pm 1.9$ & $0.0 \pm 0.1$ & $+5.1 \pm 2.1$ & $+0.2 \pm 0.6$ & $-3.6 \pm 0.7$ \\
\hline With cimetidine & $+19 \pm 14$ & $+3.4 \pm 1.7$ & $0.0 \pm 0.1$ & $+3.4 \pm 1.4$ & $+0.7 \pm 0.6$ & $-4.1 \pm 0.4$ \\
\hline
\end{tabular}

* No differences are statistically significant.

bonate-free solution, the $\mathrm{pH}$ increased slightly as the test solution traversed the test segment. The $\mathrm{PCO}_{2}$ of the collected fluid was similar to that in the perfused test solution, and the bicarbonate concentration in the test segment was $0.8-1 \mathrm{meq} / \mathrm{liter}$. These results suggest that jejunal chloride secretion is not accompanied by hydrogen ion secretion. On the other hand, when the bicarbonate-containing solution was perfused, the $\mathrm{pH}$ fell as fluid traversed the test segment, and the $\mathrm{PCO}_{2}$ of the collected fluid was higher than that of the perfused test solution. These results agree with previous data obtained in patients with gastric achlorhydria (2) (see Discussion).

Chloride secretion during perfusion of a bicarbonatecontaining solution. 2 of 80 normal subjects, perfused with a bicarbonate-containing solution in our laboratory during the previous $5 \mathrm{yr}$, secreted chloride. (The test solution was similar to solution B in Table II.) The results of these two studies are presented in Table VII. Bicarbonate was absorbed in both subjects, but water movement was close to zero. In spite of negligible movement of water, the chloride concentration in luminal fluid rose to levels much higher than the plasma chloride concentration. PD was measured in one of the subjects and was $-5 \mathrm{mV}$. Thus, the chloride secretion in this subject occurred against both a concentration and an electrical gradient. Chloride fluxes were also measured in this subject, and the observed flux ratio was less than the flux ratio calculated for passive transport. These results suggest that these two normal subjects were actively secreting chloride during perfusion of a bicarbonate-containing test solution. Neither subject was ill in any way when these studies were carried out.

\section{DISCUSSION}

Previous studies have shown that the human jejunum absorbs bicarbonate actively (against an electrochemical gradient), that this absorption process does not

TABLE VI

$p \mathrm{H}, \mathrm{P}_{\mathrm{CO}_{2}}$ and $\left[\mathrm{HCO}_{3}\right]$ during Perfusion with a Bicarbonate-free and a Bicarbonate-containing Solution in Five Normal Subjects

\begin{tabular}{lccccc}
\hline & Infusion & Proximal & $P$ value* & Distal & $P$ value \\
\hline $\mathrm{pH}$ & & & & & \\
$\quad$ Bicarbonate-free & $5.3 \pm 0.1$ & $5.8 \pm 0.1$ & 0.005 & $6.0 \pm 0.1$ & 0.005 \\
Bicarbonate-containing & $7.5 \pm 0.1$ & $7.3 \pm 0.1$ & $<0.001$ & $6.8 \pm 0.1$ & $<0.001$ \\
$P$ value & $<0.001$ & $<0.001$ & & $<0.001$ & \\
$\mathrm{P}_{\mathrm{CO}_{2} \text { (mm Hg) }}$ & & & & \\
$\quad$ Bicarbonate-free & $47 \pm 1$ & $50 \pm 2$ & $\mathrm{NS}$ & $50 \pm 1$ & $\mathrm{NS}$ \\
Bicarbonate-containing & $47 \pm 1$ & $61 \pm 2$ & 0.005 & $57 \pm 3$ & 0.025 \\
$P$ value & $\mathrm{NS}$ & $<0.001$ & & $<0.05$ & \\
[HCO ${ }_{3}$ ] (meq/liter) & & & & & \\
Bicarbonate-free & $0 \pm 0$ & $0.8 \pm 0.2$ & 0.02 & $1.0 \pm 0.2$ & 0.02 \\
Bicarbonate-containing & $40.1 \pm 0.6$ & $24.8 \pm 0.8$ & $<0.001$ & $7.0 \pm 1.1$ & $<0.001$ \\
$P$ value & $<0.001$ & $<0.001$ & & $<0.01$ & \\
\hline
\end{tabular}

Cimetidine was administered to decrease gastric acid secretion.

There was no statistically significant difference in $\mathbf{P}_{\mathrm{CO}_{2}}$ and $\mathrm{pH}$ of samples from proximal and distal collecting sites.

* $P$ value between infusion and proximal collecting site.

$\ddagger P$ value between infusion and distal collecting site. 
TABLE VII

Chloride Secretion in Two Normal Subjects during Perfusion of a Bicarbonate-containing Solution

\begin{tabular}{|c|c|c|c|c|c|c|c|c|c|c|c|c|}
\hline \multirow[b]{2}{*}{ Subject } & \multicolumn{3}{|c|}{$\begin{array}{c}\text { Chloride } \\
\text { concentration* }\end{array}$} & \multicolumn{3}{|c|}{$\begin{array}{l}\text { Bicarbonate } \\
\text { concentration* }\end{array}$} & \multicolumn{4}{|c|}{ Net movement $t$} & \multicolumn{2}{|c|}{ PD } \\
\hline & Inf & Prox & Dist & Inf & Prox & Dist & $\mathrm{H}_{2} \mathrm{O}$ & $\mathrm{Na}$ & $\mathrm{HCO}_{3}$ & $\mathrm{Cl}$ & Direct & Indirect \\
\hline WM & 105 & 121 & 130 & 35 & 23 & 10 & -15 & -4 & -8 & +4 & - & - \\
\hline GW\$ & 106 & 119 & 129 & 35 & 20 & 16 & +6 & +2 & -2 & +5 & -5 & -3 \\
\hline
\end{tabular}

* Inf = infused solution; prox = aspirate obtained at proximal collecting site; dist = aspirate obtained at distal collecting site. $\ddagger(-)=$ absorption; $(+)=$ secretion.

$\S$ In subject $\mathrm{GW}$, serum chloride concentration was $103 \mathrm{meq} / \mathrm{liter}$.

generate an electrical potential difference across the mucosa, and that bicarbonate absorption is mediated by hydrogen ion secretion rather than by bicarbonate ion absorption (2). Sodium is also actively absorbed by the jejunum, but only when the luminal fluid contains bicarbonate. These observations have suggested that a $\mathrm{Na}^{+} / \mathrm{H}^{+}$exchange is the mediator of active sodium bicarbonate absorption by the human jejunum. This active sodium bicarbonate absorption results in the passive absorption of water, sodium chloride, and potassium chloride. As far as we can tell, in the absence of luminal bicarbonate or some actively absorbed nonelectrolyte such as glucose, the human jejunum does not actively absorb sodium or any other electrolyte.

Much earlier work (1) has suggested that the normal small bowel is also a secretory organ, but that this function is masked by more powerful absorptive forces (see Introduction). It was our purpose to evaluate this hypothesis. It seemed possible to do this by removing bicarbonate from the luminal perfusion fluid; in the absence of bicarbonate, active sodium bicarbonate absorption is eliminated, and passive absorption of water and electrolytes secondary to absorption of sodium bicarbonate is correspondingly reduced. Thus, if the normal jejunum secretes as well as absorbs, the secretion should become apparent during perfusion of a bicarbonate-free solution.

Therefore, we perfused the jejunum with an isotonic, bicarbonate-free, sulfate-containing solution, and under these conditions the jejunum secreted water, sodium, and chloride (Table II). These experiments therefore confirmed the hypothesis that the human jejunum is a secretory as well as an absorptive organ.

To identify the ion that is actively secreted during perfusion of a bicarbonate-free solution, we repeated the experiment in a larger number of subjects and measured potential difference and bidirectional fluxes of sodium and chloride. These studies suggested that sodium secretion was passive, in accordance with electrochemical gradients. On the other hand, the chloride secretion was apparently active, in that chlo- ride was secreted against an electrochemical gradient, and the chloride flux ratios were not consistent with passive chloride movement according to Ussing's equation. The only possible driving force for passive chloride secretion during this experiment was water secretion at an average rate of $12 \mathrm{ml} / \mathrm{h}$ per $30 \mathrm{~cm}$. However, it seems doubtful that this small water secretion rate could cause the observed chloride secretion. Furthermore, the calculated concentration of chloride in secreted fluid was $\sim 310 \mathrm{meq} / \mathrm{liter}$ (water secretion rate $12 \mathrm{ml} / \mathrm{h}$, chloride secretion rate $3.7 \mathrm{meq} / \mathrm{h}$ ); if chloride secretion were passive, secondary to water secretion (solvent drag), the concentration of chloride in the secreted fluid would be less than the chloride concentration in plasma.

Before we can conclude that active chloride secretion is a property of the normal jejunum, two factors related to our experimental design need to be considered. First, in the data discussed so far, sulfate replaced bicarbonate in the bicarbonate-free solution, and it is conceivable that high luminal concentrations of sulfate might somehow stimulate chloride secretion, perhaps by a sulfate-chloride exchange. Therefore, additional studies were carried out wherein the perfusing solution did not contain sulfate (Table IV), and active chloride secretion was still evident. Therefore, chloride secretion cannot be attributed to high luminal sulfate concentration. Second, during perfusion of bicarbonatefree solution, the $\mathrm{pH}$ of luminal fluid was 5.8-6.0, raising the possibility that the observed chloride secretion is somehow a function of low luminal fluid $\mathrm{pH}$ rather than an intrinsic property of the normal jejunum. There are two arguments against this possibility. First, we have occasionally observed chloride secretion in normal subjects during perfusion with a bicarbonatecontaining solution (Table VII) when the luminal pH would be $>7.0$. Therefore, chloride secretion can occur in normal subjects at higher luminal $\mathrm{pH}$ than is present when bicarbonate-free solutions are perfused. Second, the "normal" $\mathrm{pH}$ of the fasting luminal contents is about 6.5 (2). Presumably, this is due to acid secretion 
by the jejunum, probably $\mathrm{Na} / \mathrm{H}$ exchange (see first paragraph of Discussion). Furthermore, the $\mathrm{pH}$ of postcibal jejunal contents is $4-7$ (14). Therefore, the $\mathrm{pH}$ of luminal contents during perfusion of the bicarbonatefree solution is not abnormal.

Thus, we conclude that the normal jejunum actively secretes chloride in vivo. The magnitude of this secretion was variable, but averaged $4 \mathrm{meq} / \mathrm{h}$ per $30 \mathrm{~cm}$ of jejunum. To put this in perspective, this value can be compared with the other active anion transport process in the human jejunum, bicarbonate absorption, which occurs at a rate of $16 \mathrm{meq} / \mathrm{h}$ per $30 \mathrm{~cm}$ when luminal contents contain bicarbonate in a concentration equal to that in plasma (Table II). Thus, the normal bicarbonate absorption rate is about four times greater in magnitude than the normal chloride secretion rate. However, the greater magnitude of bicarbonate absorption is probably only one reason why the anion absorptive force (bicarbonate) exceeds the anion secretory force (chloride) during perfusion of balanced test solutions. Another is that the jejunal mucosa is impermeable to bicarbonate, but highly permeable to chloride (15). Therefore, active absorption of a milliequivalent of bicarbonate is probably more efficient than active secretion of a milliequivalent of chloride, because there is less passive back leak of transported bicarbonate.

Nevertheless, we believe that the rate of active chloride secretion may be partially responsible for the variable net rate of absorption or secretion observed in different normal subjects. For example, we suspect that high to normal rates of chloride secretion may be responsible for the net secretion of water and electrolytes observed in a small fraction of normal subjects when their jejunum is perfused with a bicarbonate-containing test solution (Table VII).

Our observations strongly suggest that the normal jejunum actively secretes chloride, but they reveal no evidence as to the site of this secretory process, i.e., crypt cells, villous cells, or both. In addition, our studies do not reveal the mechanism of the active chloride secretion. The data do suggest, however, that the chloride secretion is not dependent on $\mathrm{H}_{2}$-receptors, since it was not inhibited by cimetidine, and that hydrogen does not accompany chloride in the secretory process. At the present time, we have no further insight into the mechanism of jejunal chloride secretion.

It is theoretically possible that the chloride secretory process we have observed in the normal jejunum is the same chloride secretory process that is stimulated by cholera toxin or other agents that enhance mucosal cyclic AMP concentration. On the other hand, it is also possible that such "secretagogues" cause chloride secretion mainly by inhibiting normal absorption and thus unmasking normal chloride secretion. Further studies are required to settle this question.
If the normal human jejunum secretes normally, one might expect this to have been evident from in vitro studies when the potential difference was shortcircuited. One group of workers studied the human jejunal mucosa under short-circuited conditions (16), and no statistically significant chloride absorption or secretion was observed. However, a bicarbonatecontaining solution was used in this in vitro study, and perhaps water movement, in response to sodium bicarbonate absorption, might have stimulated passive chloride absorption and thus masked active chloride secretion. It would seem worthwhile to repeat this in vitro experiment with a bicarbonate-free medium on the luminal side of the mucosa. In vitro results in animals are conflicting. A short-circuited preparation of rat jejunum secreted chloride (17), whereas a similar study in the rabbit revealed no active transport of chloride (18). Thus, it is possible that active chloride secretion by the normal jejunum may vary in different species.

\section{ACKNOWLEDGMENTS}

The authors express their appreciation to Ms. Jean Harber for her excellent assistance in preparation of this manuscript.

This work was supported by the Department of Health, Education, and Welfare Research Grant 5-R01-AM06506 from the National Institute of Arthritis, Metabolism, and Digestive Diseases, and the Southwestern Medical Foundation's Abbie K. Dreyfuss Fund, Dallas, Texas.

\section{REFERENCES}

1. Florey, H. W., R. D. Wright, and M. A. Jennings. 1941. The secretions of the intestine. Physiol. Rev. 21: 36-69.

2. Turnberg, L. A., J. S. Fordtran, N. W. Carter, and F. C. Rector. 1970. Mechanism of bicarbonate absorption and its relationship to sodium transport in the human jejunum. J. Clin. Invest. 49: 548-556.

3. Cooper, H., R. Levitan, J. S. Fordtran, and F. J. Inglefinger. 1966. A method for studying absorption of water and solute from the human small intestine. Gastroenterology. 50: 1-7.

4. Read, N. W., and J. S. Fordtran. 1979. The role of intraluminal junction potentials in the generation of the gastric potential difference in man. Gastroenterology. 76: 932-938.

5. Moore, W. L., F. A. Bieberdorf, S. G. Morawski, R. A. Finkelstein, and J. S. Fordtran. 1971. Ion transport during cholera-induced ileal secretion in the dog. J. Clin. Invest. 50: $312-318$.

6. Turnberg, L. A. 1971. Potassium transport in the human small bowel. Gut. 12: 811-818.

7. Bieberdorf, F. A., P. Gorden, and J. S. Fordtran. 1972. Pathogenesis of congenital alkalosis and diarrhea: implications for the physiology of normal ileal electrolyte absorption and secretion. J. Clin. Invest. 51: 1958-1968.

8. Fordtran, J. S. 1975. Stimulation of active and passive sodium absorption by sugars in the human jejunum. $J$. Clin. Invest. 55: 728-737.

9. Ussing, H. H. 1960. Active and passive transport of the alkali metal ions. In The Alkali Metal Ions in Biology. Handbook of Experimental Pharmacology. SpringerVerlag, Heidelberg. 13: 45-143. 
10. Hyden, S. 1955. A turbidometric method for determination of higher polyethylene glycols in biological material. Ann. Agr. Coll. (Sweden). 22: 139-145.

11. Fordtran, J. S., F. C. Rector, M. F. Ewton, N. Soter, and J. Kinney. 1965. Permeability characteristics of the human small intestine. J. Clin. Invest. 44: 1935-1944.

12. Berger, E. Y., and J. M. Steele. 1958. The calculation of transfer rates in two compartment systems not in dynamic equilibration. J. Gen. Physiol. 41: 1135-1152.

13. Ussing, H. H. 1949. The distinction by means of tracers between active transport and diffusion. The transfer of iodide across the isolated frog skin. Acta Physiol. Scand. 19: 43-56.

14. Fordtran, J. S., and T. W. Locklear. 1966. Ionic constitu- ents and osmolality of gastric and small intestinal fluids after meals. Am. J. Dig. Dis. 11: 503-521.

15. Fordtran, J. S., F. C. Rector, and N. W. Carter. 1968. The mechanism of sodium absorption in the human small intestine. J. Clin. Invest. 47: 884-900.

16. Corbett, C. L., P. E. T. Isaacs, A. K. Riley, and L. A. Turnberg. 1977. Human intestinal ion transport in vitro. Gut. 18: 136-140.

17. Munck, B. G. 1972. Effect of sugar and amino acid transport on transepithelial fluxes of sodium and chloride of short-circuited rat jejunum. J. Physiol. (Lond.). 223: 699-717.

18. Fromm, D. 1973. $\mathrm{Na}$ and $\mathrm{Cl}$ transport across isolated proximal small intestine of the rabbit. Am. J. Physiol. 224: $110-116$. 